\title{
Strategies Used in Rendering Humor in Translations of "A Man Called Ove" by Fredrick Backman
}

\author{
Fatemeh Ghanbar Beheshti Amir Mahdavi Zafarghandi \\ Department of English Language, Rahman, Ramsar, Iran
}

\begin{abstract}
In the current study, two translations by Farnaz Taimorzuv (2017) and Hossein Tehrani (2016) of the book "A Man Called Ove" by Fredrick Backman, which is abundant in humor, were selected. The transition of humor from the source language to the target language was investigated by the syntactic strategy of Chesterman (2016). During the analysis of humor, the humorous excerpts were identified. Afterwards, the transference of humorous effects was investigated in both Persian translations. The results showed that, in translation of humor at the linguistic level, the translators have not been fully successful. Neither have they effectively rendered malapropism. Finally, in translation of repetition and parallelism, Taimorzuv applies some strategies to transfer the humoristic effect to the target text, whereas Tehrani seems to have ignored the aesthetic values of the source text.
\end{abstract}

Keywords: Satire, humour, translation strategy, comparative study

DOI: $10.7176 / J L L L / 72-04$

Publication date:October $31^{\text {st }} 2020$

\section{Introduction}

Humor can be both in verse and prose. It challenges the human's errors or unfavorable behavior, sociopolitical deviations, and philosophical notions. Humor has a significant statue in literature. It goes back to the entrance of the theatre to Greece and Rome. In Iran, the tendency to use humor goes back to the Persian classical verse and prose (Hossieni, Mobaraki, \& Rabani Nia, 2017).

\section{Significance of the study}

Humor is an extremely powerful artistic structure which is used to criticize particular human behaviors. In addition to the content, form is also significant in humoristic task. It is a tool used by a poet and a creative author. Humoristic or some satirical pieces can be seen in literary words, in nearly all languages. As a result, having the knowledge of translating humor is valuable. The translator requires some guidance or theories to transfer the humoristic affects into the Target text. Translators should know some strategies which make the humor of the Source text more prominent for the readers of the Target text, recreating a proper translated piece of literature (Hossieni et al., 2017). This research is accomplished in order to discover the humoristic tools applied in a notable satirical novel, "A Man Called Ove", and to explore different strategies which are used in translating humoristic tools.

\section{Research questions}

Were the translators able to reproduce the same humoristic features of the source text in the target text by applying the presented strategies? Which translator was more successful in transference of humor?

\section{Research hypothesis}

Both translators could reproduce the humoristic feature by applying the presented strategies.

\section{Types of humor}

Accordingly, it is clear that among these literary devices there are so many overlapping devices which lead to more confusion in understanding the intention of the author. In this study, two linguistic features in humor are examined: repetition and parallelism.

Repetition: In her thesis, Broeder (2007) stated that the item from the source text is not changed but is directly moved into the target text. All or several formal features of the item are recreated in the target text with no considering maximum semantic equivalence.

Repetition is a literary device in which the same words or phrases repeat more than once to make an idea clearer and more memorable. There are several kinds of repetition generally used in both prose and poetry. As a rhetorical device, it could be a word, a phrase, or a full sentence, or a poetical line repeated to emphasize its significance in the whole text (Literary Devices Editors, 2018b).

Parallelism refers to the use of elements in a sentence that grammatically or in their construction, sound, meaning, or meter are the same. Parallelism examples are seen in literary works and in common conversations (Literary Devices Editors, 2018a). 


\section{Translation of humor}

Huang (2011) believes that, in literary translation, not only the common features of the source text need to be regarded but also the effective elements from the target view such as the linguistic and cultural differences and the target audiences must be regarded. Literary texts are specified by rhetorical and aesthetic principles, which are expected to be taken and preserved in a literary translation. One of the essential duties of the literary translator is to recreate the rhetorical and aesthetic principles of the original text. In literary translation, the form connects to the content; but in non-literary translation, the content may be considered separable from the form or structure. In prose, like poetry, a definite linguistic feature can also have a definite textual function.

Rener (1989, p.161) says that a 'rhetorical' term is "a carefully and skillfully assembled construction".

Content and form have an effect on each other. Venuti (2012, p. 157) believes that "the content of a message can never be completely abstracted from the form and form is nothing apart from content". The linguistic diversities, however, create a great challenge in literary translation. In prose, the linguistic diversities should also be cautiously considered Venuti( 2012).

Liu Lei (2010) believes that humor is distributed between people from every nation. However, various nations have different kinds of perception of humor, nearly related to religion, ideology, society, politics and culture. Therefore, however humor has been examined for a very long time, most are from the point of literature, art, sociology, psychology, pragmatics or linguistics view. Some scholars are uncertain that humor can be fully translated into another language because humor is language-specific and culture-specific. Just a few scholars investigate the translation of humor.

According to Attardo (1994), we have two kinds of jokes, referential and verbal jokes. The referential one is based exclusively on the meaning of the text and do not make any reference to the phonological perception of the lexical items, while the second, additionally to being based on the meaning of the elements of the text, make reference to the phonological perception of the text.

Referential jokes refer to humor which focused on the pragmatic level and plays with language. whereas, verbal jokes refer to humor which focused on the linguistic level and plays through language.

Concerning humor at the linguistic level Gledhill (2003) states that the translation of humor and pun is still an abandoned scope in literary translation theory.

\section{Fredrick Backman's humor}

As stated before, the focus of the present research is "A Man Called Ove" and its two Persian translations. The logic behind choosing this work as the focus of this study is that Backman is a famous satirist and this novel is a rich resource of satire and humor.

\section{Theoretical framework}

What translators need is to translate with a theory which makes some sense to them. To translate without perception or understanding and with no self-awareness, no self-criticism it would mean trusting entirely on common sense, one might say (Chesterman, 1993).

According to Chesterman (2000), Strategy memes are the most effective sets of professional translation memes. These memes are, in an especially obvious sense, main conceptual tools of the translator's trade. By "strategy" here his mean any well-established method of solving a translation problem. These strategies are applied and well known in the profession. He believes that the difference between a professional and an amateur is that the professional generally knows at a time, or can decide quite immediately, what kind of strategy to use. Professionals can do this either because they have learned the strategies clearly during training, or because they have found them from their own experiment, or because they have imitated them from colleagues.

Chesterman (2016) specifies comprehension strategies and production strategies. Comprehension strategies deal with the analysis of the source text and the type of the translation commission. Production strategies are the results of several comprehension strategies: they deal with how the translator uses the linguistic material in order to create a proper target text.

Chesterman (2016) divides production strategies to 3 classes: semantic, syntactic and pragmatic strategies. Each class has 10 techniques. In this paper, the writer focuses on one of the techniques of syntactic strategy.

\section{Syntactic strategies}

According to Chesterman (1997, p. 94), these strategies "may be thought of as involving purely syntactic changes of one kind or another. Larger changes may obviously tend to involve smaller ones too. Syntactic strategies primarily manipulate form". Those strategies include: (a) literal translation, (b) loan, claque, (c) transposition, (d) unit shift, (e) phrase structure change, (f)clause structure change, (g) sentence structure change, (h)cohesion change, (i)level shift, and (j) scheme change.

Scheme change: Chesterman (1997, p. 99) said that "this refers to the kinds of changes that translators incorporate in the translation of rhetorical schemes such as parallelism, repetition, alliteration, metrical rhythm, 
etc."

Chesterman (1997, p. 100) stated that the translator may choose between three basic alternatives:

1. ST scheme $X \rightarrow$ TT scheme $X$. That is, if the ST scheme is judged to be appropriate to the translation practice, it can be (to some extent) maintained: in fact, no change.

2. ST scheme $\mathrm{X} \rightarrow \mathrm{TT}$ scheme $\mathrm{Y}$. That is, the ST scheme can be changed to another scheme that is considered to serve a proper or similar function in the TL.

3. ST scheme $X \rightarrow$ TT scheme $ø$. That is, the scheme is abandoned altogether.

4. ST scheme $\varnothing \rightarrow$ TT scheme X. Here, the translator decides to use a rhetorical scheme of some kind, although not prompted directly to do so by the ST.

\section{Review of literature}

The research on humor is a wide field, and many researchers have worked on it. The purpose of this study is to focus on the translation of humor. Salvatore's (1994) general theory of verbal humor concentrated on linguistic methods of humor translation. He presented six parameters for producing humor. Using these six parameters helps translators to recreate the humor in the target language.

\section{Methodology}

Corpus

As mentioned above, to investigate the extent that the translators had been successful in transferring humor using strategies, a book entitled "A Man Called Ove" written by Swedish columnist Fredrik Backman (2012) was chosen. The target texts that were used were two translated versions of "A Man Called Ove". Farnaz Taimorzuv translated the first target text (TT1). She is an Iranian translator of works from English into Persian. And Hossein Tehrani translated the second target text (TT2).

\section{Data collection}

The researcher analyzed different models, approaches as well as quotes and suggestions by the scholars in the field of parallelism, repetition, and wordplay translation in order to come up with a model for the translation of humor. In this study, the unit of investigation was text. The first step in data collection was to recognize and find parallelism and repetition in English text and its translations. Therefore, 337 pages (all pages) of the novel and their translations were studied in order to find 30 examples of repetition and 20 examples of parallelism.

\section{Procedure process}

Firstly, the researcher tried to recognize parallelism and repetition in the source text and found their equivalents in the target texts. Then, each translation version was compared and contrasted based on scheme change strategy to see whether it was applied. After specifying the strategy applied by each translator, the tables are drawn as follow.

\section{Data analysis}

1 - When Parvaneh, with panic in her eyes, runs right into Ove's hall and continues into the bathroom without even bothering to say "Good morning. "Ove immediately disputes how one can become so acutely in need of a pee in the space of twenty seconds it takes her to walk from her own house to his. But "hell has no fury like a pregnant woman in need," Sonja once informed him. So, he keeps his mouth shut. (Backman,2014, p. 298)

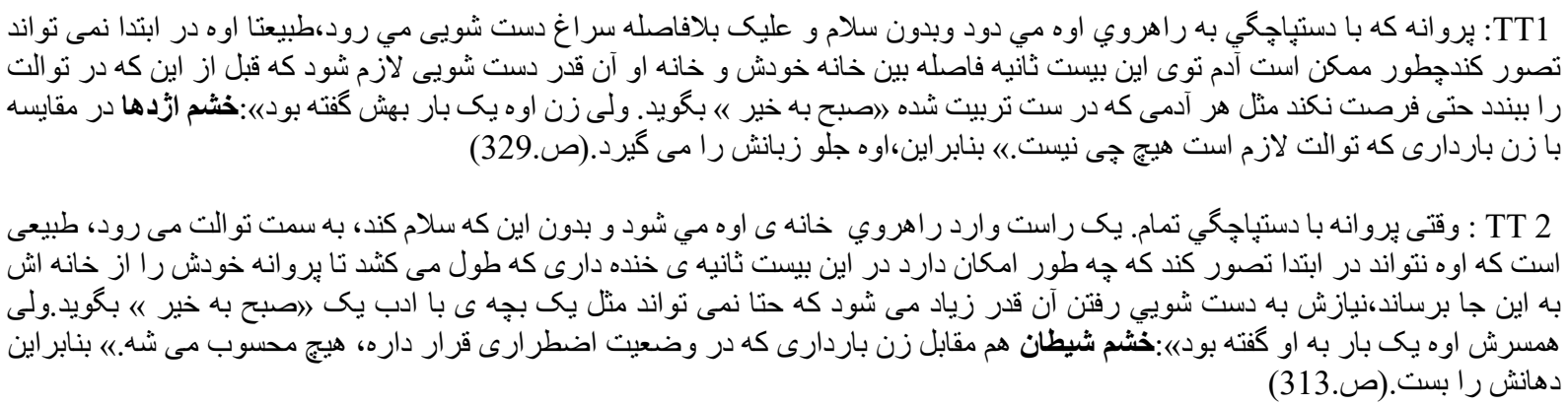

Both translators have used syntactic strategy in this humorous statement. They used the second subclass of Scheme change which is ST scheme X $\rightarrow$ TT scheme X, because "خشم ازدها" and "خشيطان" are relevant to "helll".

2 - And, as Ove's wife often says: "If there's one thing you could write in Ove's obituary, it's "At least he was economical with gas." (Backman,2014, p.29) 
داد. "TT1 : و به قول زن اوه: 》ا اكه يه جيز باثه كه آدم بتونه توى آكهى فوت اوه بنويسه، اينه كه او هميشه به ميزان مصرف سوخت توجه نشان مى

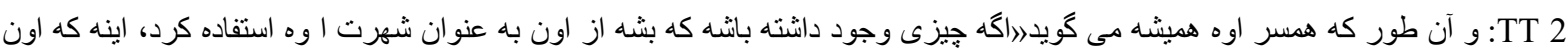

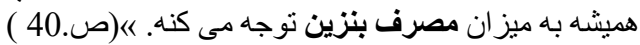

Taimorzuv used semantic strategy to translate it. She used the second subclass of hyponymy which is ST hyponomy $\rightarrow$ TT superordinate because "gas" is more specific than "سوخت". Tehrani used the syntactic strategy; he used the first subclass of Scheme change which is ST scheme X $\rightarrow$ TT scheme X because "بنزين" is the same as "gas".

3 _He hated being late. It ruined the planning. Made everything out of step. His wife had been utterly useless at it, keeping to plans. But it was always like that with women. They couldn't stick to a plan even if you glued them to it, Ove had learned. (Backman,2014, p. 140)

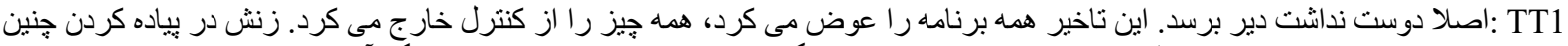

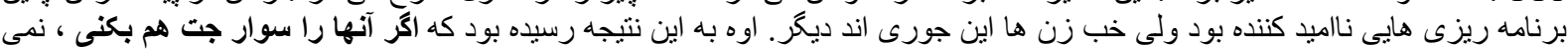

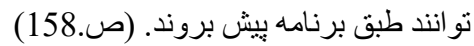

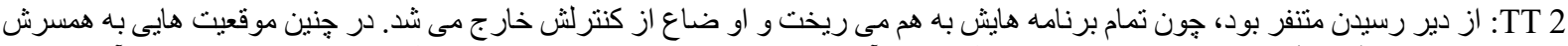

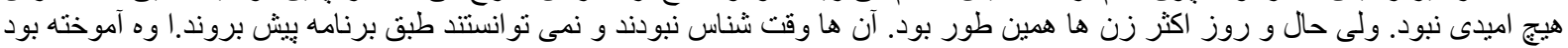

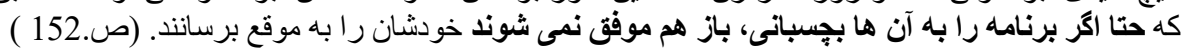

Taimorzuw used the second subclass of Scheme change which is ST scheme X $\rightarrow$ TT scheme Y, because of adding the phrase " اكر آنها را سوار جت هم بكنى “, that stands for "if you glued them to it”. Tehrani used the first subclass which is ST scheme $X \rightarrow$ TT scheme $X$.

4- “It’s me who’s bloody dying!” Ove objects. (Backman,2014, p. 329)

$$
\begin{aligned}
& \text { TT1 : اوه مخالفت مى كند: "اين منم كه بايد بميرم!" (ص.363) } \\
& \text { :346. اوه مى كويد" اونى كه داره مى ميره, منم نه نو !" (ص22 }
\end{aligned}
$$

Both translators used the first subclass of scheme change which is ST scheme X $\rightarrow$ TT scheme because Taimorzuv used " اين منم كه بايد بميرم "for the rendition of “It's me who's bloody dying!” and Tehrani presented "!

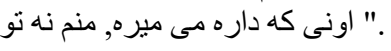

5 - "If you start crying now, you're not having it," warns Ove. (Backman,2014, p. 300)

$$
\begin{aligned}
& \text { TT1 اوه به زن اخطار مى دهد: " اخه الان شروع كنى به آبغوره كرفتن , تخت بى تخت )". ص.331 } \\
& \text { :TT2 اوه به او اخطار مى كند "اگه شروع كنى به زار زدن, اونو بهت نمى دم!" (ص.315) }
\end{aligned}
$$

Taimorzuw used the second subclass of Scheme change two times which is ST scheme X $\rightarrow$ TT scheme Y, because of adding the" آبغوره " and " تخت بى تخت " to the TT. Tehrani used the second subclass which is ST scheme $\mathrm{X} \rightarrow$ TT scheme Y.

6-Ove sighs_- "Bloody women" (Backman,2014, p. 300)

$$
\begin{aligned}
& \text { TT1 اوه فقط آه كثان مى كويد: "امان از اين زن ها." (ص.331) } \\
& \text { TT2 اوه آه كثان مى كويد: " از دست اين زن ها." (ص.315) XT2 }
\end{aligned}
$$

Both translators used the first subclass of scheme change which is ST scheme X $\rightarrow$ TT scheme X. In fact, no change happened.

7-Maybe it was because Tom had put the blame on him for the theft in the carriage. Maybe it was the fire. Maybe it was the bogus insurance agent. Or the white shirts. Or maybe it was just enough now. (Backman,2014, p. 113) 


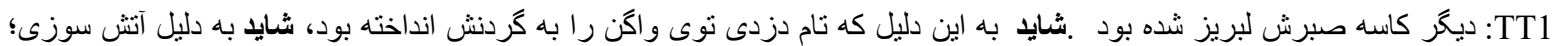

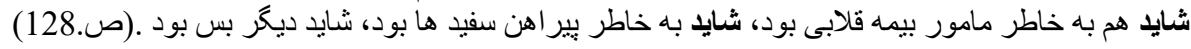

$$
\begin{aligned}
& \text { TT2: شايد به اين ربط داشت كه تام كناه دزدى كردنش را كردن او انداخته بود .شايد به آتش سوزى، شايد به بيمه هاى تقلبى. شايد به آن بير اهن }
\end{aligned}
$$

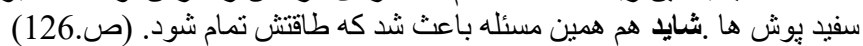

- This sentence has a special scheme as Parallelism. As said before, it is the repetition of the same pattern of words or phrases within a sentence or passage to show that two or more ideas have the same level of importance. Backman used it in his novel as a humoristic device. The structure of the five sentences above is repeated and both translators perfectly maintained the repetition based on the grammatical structure of the Persian language. Based on Chesterman's syntactic strategies, they used the scheme change strategies to translate these sentences. Both translators used the first procedure which is ST scheme $\mathrm{X} \rightarrow \mathrm{TT}$ scheme $\mathrm{X}$. It means that the parallelism is preserved.

8 -"Rules are rules," the man in the white shirt explained in a monotone voice when Ove protested. (Backman,2014, p. 95)

$$
\begin{aligned}
& \text { (107. اوه اعتر اض كرد، يِر اهن سفيد باصر احت توضيح داد :» قانون قانونها《. ( ص :TT1 }
\end{aligned}
$$

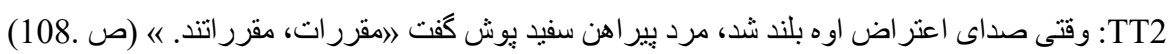

The term "Rules" is repeated two times. Taimorzuv translated both of them as "قانون " but Tehrani translated them as "مقررات". Therefore, both translators have used the first strategy of the scheme change. Taimorzuv has

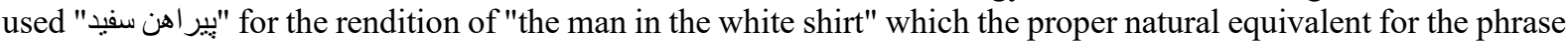
is "مرد سفيد يُوش"

Table 1. The Frequency of Strategies Used in Translation of Repetition

\begin{tabular}{lll}
\hline ST scheme $X \rightarrow$ ST scheme $X \rightarrow$ ST scheme $X \rightarrow$ ST scheme $\varnothing \rightarrow$ \\
Scheme change
\end{tabular}

\begin{tabular}{lllll}
\hline TT1 & 27 & 0 & 3 & 0 \\
\hline TT2 & 4 & 0 & 26 & 0 \\
\hline
\end{tabular}

Table 2. The Frequency of Strategies Used in Translation of Parallelism

\begin{tabular}{lcccc}
\hline \multirow{2}{*}{ Scheme change } & $\begin{array}{c}\text { ST scheme } \mathrm{X} \rightarrow \text { ST scheme } \mathrm{X} \rightarrow \text { ST scheme } \mathrm{X} \rightarrow \text { ST scheme } \varnothing \rightarrow \\
\text { TT scheme } \mathrm{X}\end{array}$ & TT scheme Y & TT scheme $\varnothing$ & TT scheme $\mathrm{X}$ \\
TT1 & 20 & 0 & 0 & 0 \\
\hline TT2 & 4 & 0 & 16 & 0 \\
\hline
\end{tabular}

\section{Discussion}

As illustrated above, two translators transferred parallelism and repetition in different ways. As it is shown in the Table 1, 30 instances of repetition were identified and investigated. Taimorzuv used the first strategy of Scheme change which is ST scheme $\mathrm{X} \rightarrow$ TT scheme $X$, in $90 \%$ of instances and the third strategy which is ST scheme X $\rightarrow$ TT scheme $\varnothing$, in $10 \%$ of instances. These results showed that he could transfer the humoristic effect of repetition in most cases. It was also shown that Tehrani used the first strategy in four instances and the third one in 26 instances. It is clear that Taimorzuv is more faithful to the linguistic form of the ST and the first strategy is the best one in conveying the repetition which is a humoristic device in this novel. According to Table 2, 20 examples of parallelism were investigated. Taimorzuv used the first strategy in all 20 instances, but Tehrani used the first strategy in $20 \%$ of examples and the second one in $80 \%$ of examples. It seems that Taimorzuv created the same effect in the TT in all cases, but Tehrani could not transfer the humoristic effect.

\section{Conclusion}

As mentioned above, translation of humor has an important position in the literary translation. The linguistic and cultural features of humor make some problems in translation. Because of the unequal structures of the source and target language, the translator encounters difficulties in translating linguistic features of humor. Therefore, the investigation of the transference of humor is a significant field in comparative literature. In order to produce a version which contained the same humorous effects of the original, the translator should be able to utilize creative strategies. According to the tables, it can be said that the two translators rendered completely different and used 
different strategies. Generally, Taimorzuv could transfer repetition and parallelism to the target language, but Tehrani was not successful in its transference and could not recreate humor in the target text. The results of this study fostered several points of discussion such as the problems with transferring humor, the amount of creativity a translator can use, and different strategies of scheme change, which can be used in translating parallelism and repetition as two humoristic tools. The findings of this study may be useful for translators entering the area of literary translation and humoristic works. The results can also be used in the evaluation of a translated satirical work.

\section{References}

Attardo, S. (1994). Linguistic theories of humor. Humor research: Vol. 1. Berlin: Mouton de Gruyter.

Backman, F. (2014). A man called Ove: A novel (First Atria Books hardcover edition). New York: Atria Books.

Broeder, L. (2007). Translating humor.

Chesterman, A. (1993). Translation as theory: Kaantaja.

Chesterman, A. (1997). Memes of Translation (Vol. 22). Amsterdam: John Benjamins Publishing Company.

Chesterman, A. (2000). Memetics and translation strategies. Synapse, 5, 1-17.

Chesterman, A. (2016). Memes of translation: The spread of ideas in translation theory / Andrew Chesterman, University of Helsinki (Revised Edition). Benjamins translation library, 0929-7316: volume 123. Amsterdam, Philadelphia: John Benjamins Publishing Company.

Delabastita, D. (2004). Wordplay as a translation problem: A linguistic perspective. -bersetzung, Translation, Traduction, 600-606.

Gledhill, J. R. M. (2003). Strategies in Translation: A Comparison of the Helen Lowe-Porter and David Luke Translations of Thomas Mann's Tonio Krger, Tristan and Der Tod in Venedig Within the Context of Contemporary Translation Theory. Universitat Erfurt.

Hossieni, R. B., Mobaraki, M., \& Rabani Nia, M. (2017). A Comparative Study of Transference of Humor in Translations of "The Adventures of Huckleberry Finn" by Mark Twain. International Journal of Applied Linguistics and English Literature, 6(6), 1. https://doi.org/10.7575/aiac.ijalel.v.6n.6p.1

Huang, X. (2011). Stylistic approaches to literary translation: With particular reference to English-Chinese and Chinese-English translation. University of Birmingham.

LiteraryDevices Editors. (2018). Parallelism. Retrieved from https://iterarydevices.net/parallelism/

LiteraryDevices Editors. (2018). Repetition. Retrieved from https://iterarydevices.net/repetition/

Liu, L. (2010). Translation of Humor in Ch'ien Chungshu's "Fortress Besieged" in Jeanne Kelly and Nathan K. Retrieved from http://digital.library.wisc.edu/1793/43583

Maher, B. (2011). Recreation and style: Translating humorous literature in Italian and English / Brigid Maher. EST subseries: v. 90. Amsterdam, The Netherlands, Philadelphia, PA: John Benjamins Pub.

Rener, F. M. (1989). Interpretatio: Language and translation from Cicero to Tytler. Approaches to translation studies: v.8. Amsterdam: Rodopi.

Vandaele, J. (2010). Humor in translation. Handbook of Translation Studies, 1, 147-152.

Venuti, L. (2012). The Translation Studies Reader: Routledge.

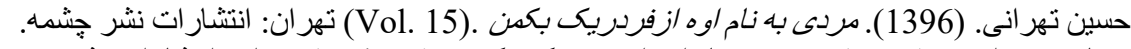
فرناز تيمور ازف. (1396). مردي به نام اوه /زفردريكى بكعن . (Vol. 24) تهر ان: انتشار ات نشر نون. 